\title{
Azomonas macrocytogenes (ex Baillie, Hodgkiss, and Norris 1962, 118) nom. rev.
}

\author{
P. B. NEW AND Y. T. TCHAN \\ Department of Microbiology, University of Sydney, New South Wales, 2006, Australia
}

\begin{abstract}
The name Azomonas macrocytogenes (Jensen) Baillie, Hodgkiss, and Norris 1962, 118 is not in the Approved Lists of Bacterial Names. The organism to which this name refers does not belong to the genus Azotobacter, although the name Azotobacter macrocytogenes Jensen 1955, 280 was included in the Approved Lists. Reasons are presented for including the organism in the genus Azomonas, and the name Azomonas macrocytogenes is revived. The type strain is ATCC 12335 .
\end{abstract}

The name Azomonas macrocytogenes (Jensen 1955) Baillie, Hodgkiss, and Norris 1962, 118 does not appear in the Approved Lists of Bacterial Names (9), although it was accepted in the 8th edition of Bergey's Manual (3) and was included in the first draft of the Approved Lists (1). Instead, the former name of this organism, Azotobacter macrocytogenes Jensen 1955, 280, was given in the Approved Lists, and the new combination Azomonotrichon macrocytogenes (Jensen 1955) Thompson and Skerman 1981, 215 has since been validly published (6). The purpose of this report is to revive the name Azomonas macrocytogenes (used hereafter) and to effect its valid publication, as specified in Rules 27, 28a, and 34a and Provisional Rules A2, B2, and $\mathrm{B} 3$ of the International Code of Nomenclature of Bacteria (8).

This aerobic, nonsymbiotic, nitrogen-fixing organism was originally included by Jensen in the microcyst-forming genus Azotobacter, although the author was not certain whether cysts are actually formed (7). Baillie et al. (2) assigned the organism to the genus Azomonas on the basis of polar flagellation and lack of cyst formation. However, Thompson and Skerman (11) have reported cyst formation by four of seven strains. The discrepancies in the reports may be reconciled by the electron microscopic study of Tchan (10), which shows that the cystlike cells of Azomonas macrocytogenes are surrounded by a thick layer of capsular-like material rather than the layered outer wall of a typical cyst of Azotobacter.

On the basis of a numerical taxonomic study, Thompson and Skerman (11) excluded AzOmonas macrocytogenes from the genera Azomonas and Azotobacter and placed it in the new genus Azomonotrichon. The exclusion of this organism from the genus Azotobacter is supported by deoxyribonucleic acid base composition and homology studies (4) and ribosomal ribonu- cleic acid cistron similarities (5); however, the exclusion from the genus Azomonas is not so justifiable. Azomonas macrocytogenes and Azomonas insignis are more similar to each other than to the third member of the genus, Azomonas agilis, in terms of flagellation (2) and deoxyribonucleic acid base composition (4). Although the three species differed as much from one another as from species of Azotobacter in terms of their ribosomal ribonucleic acid cistrons, de Smedt et al. (5) proposed that all three species should be included in the genus Azomonas until more information becomes available.

We therefore propose the revival of the name Azomonas macrocytogenes. The organism has been described previously $(3,11)$. The type strain is ATCC 12335 (= strain O of Jensen [7] = NCIB $8700=$ WR 111).

\section{REPRINT REQUESTS}

Address reprint requests to: P. B. New, Department of Microbiology, University of Sydney, New South Wales, 2006, Australia.

\section{LITERATURE CITED}

1. Ad Hoc Committee of the Judicial Commission of the ICSB. 1976. First draft: approved lists of bacterial names. Int. J. Syst. Bacteriol. 26:563-599.

2. Baillie, A., W. Hodgkiss, and J. R. Norris. 1962. Flagellation of Azotobacter spp. as demonstrated by electron microscopy. J. Appl. Bacteriol. 25:116-119.

3. Buchanan, R. E., and N. E. Gibbons (ed.). 1974. Bergey's manual of determinative bacteriology, 8 th ed. The Williams \& Wilkins Co., Baltimore.

4. De Ley, J., and I. W. Park. 1966. Molecular biological taxonomy of some free-living nitrogen-fixing bacteria. Antonie van Leeuwenhoek J. Microbiol. Serol. 32:6-16.

5. De Smedt, J., M. Bauwens, R. Tytgat, and J. De Ley. 1980. Intra- and intergeneric similarities of ribosomal ribonucleic acid cistrons of free-living, nitrogen-fixing bacteria. Int. J. Syst. Bacteriol. 30:106-122.

6. International Journal of Systematic Bacteriology. 1981. Validation of the publication of new names and new combinations previously effectively published outside the IJSB. List 6. Int. J. Syst. Bacteriol. 31:215-218.

7. Jensen, H. L. 1955. Azotobacter macrocytogenes n. sp., a 
nitrogen-fixing bacterium resistant to acid reactions. Acta Agric. Scand. 5:280-294.

8. Lapage, S. P., P. H. A. Sneath, E. F. Lessel, V. B. D. Skerman, H. P. R. Seeliger, and W. A. Clark (ed.). 1975. International code of nomenclature of bacteria. 1975 Revision. American Society for Microbiology, Washington, D.C.

9. Skerman, V. B. D., V. McGowan, and P. H. A. Sneath (ed.). 1980. Approved lists of bacterial names. Int. J. Syst.
Bacteriol. 30:225-420.

10. Tchan, Y. T. 1968. Importance of systematics of Azotobacteriaceae in the study of its ecology, p. 115-124. In J. W. Holmes et al. (ed.), Transactions of the 9th International Congress on Soil Sciences, Adelaide, vol. 2. Angus \& Robertson, Sydney.

11. Thompson, J. P., and V. B. D. Skerman. 1979. Azotobacteraceae: the taxonomy and ecology of the aerobic nitrogen-fixing bacteria. Academic Press, Inc., London. 